\title{
Correction to: Alternative Pathogen Control Chemistry of Glass Fiber-Reinforced Polyester Panels for Cooling Towers
}

Seval Bal, Nazmiye Ozlem Sanli (D, and Yusuf Menceloglu

\section{Correction to: \\ JMEPEG (2019) 28:6011-6024 \\ https://doi.org/10.1007/s11665-019-04357-9}

The following correction should be noted to the Acknowledgment section of this article: "Project numbers T-953/ 06102006" should instead read "Project numbers FYL-2016$21280 "$.

The original article can be found online at https://doi.org/10.1007/ s11665-019-04357-9.

Seval Bal, Institute of Science, Istanbul University, Istanbul, Turkey; Nazmiye Ozlem Sanli, Faculty of Science, Department of Biology, Section of Fundamental and Industrial Microbiology, Istanbul University, Istanbul, Turkey; and Yusuf Menceloglu, Faculty of Engineering and Natural Sciences, Sabanci University, Istanbul, Turkey; and Nanotego Co. Nano Technological Products Research and Development Chemical Industry and Trade Inc, Istanbul, Turkey. Contact e-mail: nosanli@istanbul.edu.tr. 